NOTE ON THE SET $Æ$ OF THE LARVÆ OF THYATIRID AND A CORRECTION.

Recently I have examined the larvæ of some European Thyatiridæe, and find the setæ arranged exactly as in our species. [See Proc. Boston Soc. Nat. Hist., I 894, p. 399.] The supplementary seta behind iii. varies a little in position, but is uniformly present. The species examined are Habrosyne derasa, Thyatira batis, Bombycia or, B. duplaris, Asphalia ruficollis, and $A$. fluctuosa. A correction must be made in my description just referred to (pp. 400-40I). The species there described in all its stages as "Thyatira scripta" is really Pseudothyatira expultrix. The following list may straighten out the matter :-

Habrosyne scripta.

I883. Thaxter, Papilio III., Iо. Describes egg and sixth stage. Pseudothyatira cymatophoroides.

I 863. Grote, Proc. Ent. Soc, Phil., II., I 24. Sixtn stage.

1883. Thaxter, Papilio III., io. Sixth stage.

I 895. Dyar, Proc. Bost. Soc. Nat. Hist., XXVI., 400. Egg, all stages (as Thyatira scripta).

Euthyatira pudens.

i889. Dyar, Can. Ent., XXI., 209. Mature larva.

Thus, the larvæ of only thirty-three per cent. of our species of Thyatiridæ are known. This is a poor showing for such a small family. Of the Notodontidæ fully sixty-six per cent. are known.

Harrison G. Dyar.

\title{
A NEW GENUS AND SPECIES IN THE APHELININA.
}

BY L. O. HOWARD, WASHINGTON, D. C.

I recently received from Mr. T. D. A. Cockerell, Las Cruces, New Mexico, a minute parasite of a Ceroplastes on Euphorbia hypericifolia from the Red Hill district of Jamaica, which was transmitted to him by Dr. M. Grabham. Both genus and species prove to be new, and are printed separately, partly for the reason that my revision of the Aphelininæ of North America has recently been published and I do not expect to do any extensive work on the subfamily again for some time, and partly for the reason that Mr. Cockerell wishes to use the names in the Journal of the Institute of Jamaica. The description follows: 


\section{Aneristus, n. gen.}

Resembles Coccophagus. Flagellum of antenna strongly flattened. Scape short, inserted just above the mouth and reaching to middle of face; pedicel short, triangular, as long as broad. Funicle joint I twice as long as pedicel, somewhat longer than broad. Funicle joints 2 and 3 each shorter than $\mathbf{I}$, and 3 shorter than 2 ; each about as broad as is joint $\mathrm{I}$ at tip. Club distinctly 3 -jointed, a little broader than funicle joint 3 ; joints $I$ and 2 of club subequal in length and each as long as funicle joint 3 . Joint 3 of club about as long as 2 , somewhat narrower at base than 2, pointed at tip. In other respects resembles Coccophagus, except that the hind tibiæ are considerably flattened and have a row of short stiff bristles above. Middle tibial spur long and slender, nearly as long as first tarsal joint.

\section{Aneristus ceroplaste, $\mathrm{n}$. sp.}

Female.-Length, $.8 \mathrm{~mm}$; expanse, r. $6 \mathrm{~mm}$.; greatest width of fore wing, $.27 \mathrm{~mm}$. Mesonotum finely and closely shagreened, with sparse, rather long, dark pile; eyes hairy. Colour black, slightly shining, all coxæ and femora black ; front and middle tibiæ and all tarsi pallid ; hind tibiæ black. Wings with a very large discal infuscated patch, covering nearly half the wing area.

Described from two specimens reared by T. D. A. Cockerell from Ceroplastes on Euphorbia hypericifolia from Jamaica.

\section{CORRESPONDENCE.}

Sir,-On looking over my paper in the Canadian Entomologist, I note one or two unfortunate errors. Page $3{ }^{\mathrm{I}} 3$, lines 8 and $\mathrm{s}$, read $C$. helloides and P.tharos in lieu of "Epixanthe" and "Pratensis." The specimens that I thought to be "epixanthe" and "pratensis" respectively were determined by Mr. Fletcher to be only varieties of "helloides" and "tharos," and the error in my paper seems to have escaped notice and correction. I may here mention that this spring I took several specimens of Lyccena scepiolus, which has hitherto appeared rather scarce in this neighbourhood. This last season has been the worst, from an entomological point of view, I have had since I came to the country. I have never seen so few insects, either Diurni or Noctuæ; and even the number of mosquitoes was considerably diminished. During May and the early part of June we had constantly frost at night, which seemed to do great damage to insect life.

E. F. Heath, The Hermitage, Cartwright, Man. 


\section{$2 \mathrm{BHL}$ Biodiversity Heritage Library}

Howard, L. O. 1895. "A new genus and species of the Aphelininae." The Canadian entomologist 27, 350-351. https://doi.org/10.4039/Ent27350b-12.

View This Item Online: https://www.biodiversitylibrary.org/item/22096

DOI: https://doi.org/10.4039/Ent27350b-12

Permalink: https://www.biodiversitylibrary.org/partpdf/14802

\section{Holding Institution}

MBLWHOI Library

\section{Sponsored by}

MBLWHOI Library

\section{Copyright \& Reuse}

Copyright Status: NOT_IN_COPYRIGHT

This document was created from content at the Biodiversity Heritage Library, the world's largest open access digital library for biodiversity literature and archives. Visit BHL at https://www.biodiversitylibrary.org. 